\title{
HUBUNGAN KECEMASAN DENGAN CARDIAC OUTPUT PADA PASIEN PRE OPERASI SECTIO CAESAREA DI INSTALASI KAMAR OPERASI RUMAH SAKIT UMUM ISLAM ORPEHA TULUNGAGUNG
}

\author{
Anis Murniati ${ }^{1}$, Yusuf Sulthon Asrori ${ }^{2}$ \\ ${ }^{1}$ (Prodi S1 Keperawatan, STIkes Hutama Abdi Husada,Tulungagung, Indonesia) \\ ${ }^{2}$ (Perawat di Instalasi Kamar Operasi, RSUI Orpeha Tulungagung) \\ e-mail : anismurniati85@gmail.com
}

\begin{abstract}
The nature of a woman is childbirth, all women at the time of labor need to have a good labour and give birth to a healthy and perfect baby. Childbirth with surgery for some mothers is a scary thing so that not a few mothers who experience anxiety before SC is done. Anxiety is a feeling that is not clear and worried because there is something that threatens one's security. Anxiety in each person is certainly not the same, this anxiety can lead to various changes in the body's system can even interfere with heart function and result in changes in cardiac output. Changes in cardiac output may result in changes in the patient's blood pressure that may affect the success of SC. This research use correlational research design with csoss sectional approach. The location of research is premedication room of operation room of ORPEHA Islamic Hospital Tulungagung with the number of 32 respondents. The results showed the mean cardiac output value of 7625.62. The results of statistical data analysis with Pearson correlation test obtained 0,001 significance results so there is an association between anxiety with cardiac output in patients with SC surgery with large correlation pearson 1, which means the strength of the relationship is very strong. This happens because anxiety can affect the production of catecholamines and cortisol, where this hormone can stimulate the occurrence of vasodilation of blood vessels resulting in blood flowing rapidly and much so that oxygen is distributed more, thus in people who are anxious will an increase in cardiac output. The conclusion of this study is that there is an association between anxiety with cardiac output in patients with preoperative sectio caesarea at the operating room installation of Islamic Orpeha tulungagung public hospital with the strength of the relationship of 1 .
\end{abstract}

Keywords: Sectio Caesarea, Cardiac Output, Anxiety

\section{Pendahuluan}

Peristiwa persalinan adalah suatu proses alami dan penting bagi seorang ibu. Persalinan dapat secara normal, akan tetapi juga banyak dalam proses persalinan yang mengalami hambatan sehingga dilakukan dengan prosedur operasi sectio caesaria (SC) (Ardat, 2014). SC adalah suatu tindakan pembedahan untuk melahirkan bayi dengan cara melakukan insisi pada dinding perut dan uterus. Tidakan Persalinan dengan cara SC ini diindikasikan karena kemacetan saat persalinan normal atau pada kondisi gawat darurat dan hanya dapat diselamatkan jika persalinan dilakukan dengan jalan operasi ( Kasdu, 2003 ).

Melahirkan dengan cara operasi bagi beberapa ibu merupakan hal yang menakutkan sehingga tidak sedikit ibu yang mengalami kecemasan sebelum dilakukan SC. Sebagian besar manusia merasa cemas dan tegang jika manghadapi situasi yang mengancam atau stres. Perasaan tersebut adalah reaksi normal terhadap stres. Kecemasan pada masingmasing pasien tentu tidak sama, hal ini dipengaruhi oleh berbagai faktor-faktor 
baik internal maupun external. (Atkinson,2003)

Bila kecemasan tidak teratasi dapat membangkitkan respon stres terhadap neuroendokrin, metabolik dan respon cardiac output. Respon metabolik terdiri dari vasokonstriksi, kenaikan karbohidrat dan lemak untuk energi serta metabolik protein. Respon neuroendokrin dan cardiac output melibatkan pergerakan mekanisme pertahanan dari tubuh seperti pengaktifan hormon yang berakibat meningkatnya volume darah dan akhirnya menyiapkan individu untuk bereaksi seperti respon melawan atau menghindar. Hormon lainnya dilepas untuk meningkatkan kadar gula darah yang bertujuan untuk menyiapkan energi untuk keperluan adaptasi, terkaktivasinya epineprin dan norepineprin denyut meningkat dan peningkatan aliran darah ke otot. Hal tersebut bisa menyebabkan pasien pra operasi kesulitan berbicara, selain itu akibat dari vasokontirksi akan menyebabkan hipertensi. Jika kecemasan tinggi dan tidak segera diatasi, akan menyebabkan penangguhan tindakan operasi. Begitu pula tingkat kecemasan yang tinggi pasca operasi, akan menyebabkan proses penyembuhan lama. (Kozier, 2010).

Bersadarkan data di RSUI ORPEHA Tulungagung tahun 2017 didapatkan $60 \%$ mengalami kecemasab sebelum dilakukan tindakan SC. Pasien merasa takut karena akan menjalani operasi Sectio Caesarea.

Tindakan pencegahan yang dilakukan agar pasien tidak mengalami kecemasan sebelum dilakukan prosedur SC adalah pentingnya dilakukan tindakan pengarahan dan pemberian penjelasan sedetail-detailnya tentang tindakan operasi pada saat melakukan inform consent selain itu perlunya menciptakan suasana yang nyaman diruang pre medikasi atau ruang tunggu pre operasi selain itu juga perlu dilakukan bimbingan pendekatan pada Tuhan YME (doa) untuk memberi rasa nyaman dan kesiapan saat operasi.
Berdasarkan uraian diatas maka peneliti ingin melakukan penelitian tentang hubungan kecemasan dengan cardiac output pada pasien pre operasi sectio caesarea di instalasi kamar operasi RSUI ORPEHA Tulungagung.

\section{Metode Penelitian}

Penelitian ini menggunakan design korelational dengan pendekatan cross sectional. Populasi pada penelitian ini adalah semua pasien yang akan melakukan operasi Sectio Caesarea ( SC ) di Ruang Instalansi Kamar Operasi RSU Islam ORPEHA Tulungagung. Teknik sampling yang digunakan adalah accidental sampling dengan jumlah sampel 32 orang responden. Analisa data dilakukan melalui beberapa tahap dimulai dengan editing, coding , skoring dan Tabulating. Kemudian dilakukan analisa data menggunakan korelasi pearson.

\section{Hasil Penelitian}

Penelitian dilakukan di Instalasi Kamar Operasi Rumah Sakit Umum Islam ORPEHA Tulungagung. Pengambilan data dilakukan pada saat pasien di ruang pre medikasi instalasi kamar operasi.

Tabel 1. Distribusi responden berdasarkan karakteristik responden

\begin{tabular}{lcc}
\hline Karakteristik & F & \% \\
\hline Usia & & \\
$<25$ & 8 & 25 \\
$25-30$ & 8 & 25 \\
$>30$ & 16 & 50 \\
Pendidikan & & \\
SD & 2 & 6,3 \\
SMP & 3 & 15,6 \\
SMA & 15 & 40,6 \\
Perguruan tinggi & 12 & 37,5 \\
\hline
\end{tabular}

Dari tabel di atas dapat dilihat bahwa mayoritas responden dalam rentang umur $>30$ tahun, tingkat pendidikan terbanyak SMA. 
Tabel 2. Nilai Kecemasan responden pre operasi SC

\begin{tabular}{clcc}
\hline No & Kecemasan & Freq & Prosentase \\
\hline 1 & Tidak cemas & 2 & 6.3 \\
2 & $\begin{array}{l}\text { Cemas } \\
\text { ringan }\end{array}$ & 9 & 28.1 \\
3 & $\begin{array}{l}\text { Cemas } \\
\text { sedang }\end{array}$ & 7 & 21.8 \\
4 & Cemas berat & 14 & 43.8 \\
\hline
\end{tabular}

Dari tabel di atas dapat dilihat bahwa jumlah responden yang mengalami cemas berat adalah $43.8 \%$.

Tabel 3. Nilai rata-rata cardiac output dan standart deviasi responden

\begin{tabular}{lll} 
& Mean & Std.Dev \\
\cline { 2 - 3 } Cardiac output & 7625.62 & 1266.25 \\
\hline
\end{tabular}

Dari tabel di atas dapat dilihat bahwa nilai mean cardiac output responden 7625,62 .

Hasil analisa data secara statistik dengan uji korelasi pearson didapatkan hasil signifikansi 0,001 dengan besar korelasi pearson 1

\section{Pembahasan}

Berdasarkan hasil penelitian didapatkan hasil rata-rata cardiac output pasien pre operasi SC adalah 7625,62. data uji statistik didapatkan signifikansi 0,000 dan nilai korelasi pearson sebesar 1.

Sentrum-sentrum dalam otak yang diduga mempunyai pengaruh penting dalam masalah emosi adalah hipotalamus retikuler aktivasi sistem (HRAS) dan sistem limbik. Pada kondisi cemas terjadi perubahan fungsional berupa perubahan hormonal dan neurotransmisi, meliputi peningkatan aktivitas noradrenergic (katekolamin) dan kadar kortisol. Fungsi hormon ini mengatur metabolisme glukosa terutama disaat stres. Hormon epinefrin timbul sebagai stimulasi otak, menjadi waswas dan siaga. Dan secara tidak langsung akan membuat indra kita menjadi lebih sensitif untuk bereaksi (Cannon, 2002).

Stres dapat meningkatkan produksi kelenjar atau hormon epinefrin. Epinefrin dapat menimbulkan vasokonstriksi pembuluh darah arteri dan memicu denyut dan kontraksi jantung sehingga menimbulkan tekanan darah naik seketika dan berakhir dalam waktu pendek. Hormon epinefrin menyebar di seluruh tubuh, dan menimbulkan tanggapan yang sangat luas. Laju dan kekuatan denyut jantung meningkat sehingga tekanan darah meningkat, kadar gula darah dan laju metabolisme meningkat, bronkus membesar sehingga memungkinkan udara masuk dan keluar paru-paru lebih mudah, pupil mata membesar, kelopak mata terbuka lebar, dan diikuti dengan rambut berdiri dan curah jantung meningkat. Cardiac Output merupakan banyaknya darah yang dikeluarkan ventrikel kiri ke dalam aorta setiap menit. Stroke volume : adalah banyaknya darah yang dikeluarkan ventrikel kiri ke dalam aorta setiap kali kontraksi ventrikel (stroke volume $=$ isi sekuncup) (sekitar $70 \mathrm{cc}$ ) (Vincent, 2008).

Terdapat kesesuaian antara hasil penelitian dengan teori dimana curah jantung meningkat secara signifikan seiring dengan peningkatan tingkat kecemasan yang dialami pasien. Hal ini terjadi dikarenakan keadaan stres akan merangsang pengeluaran hormon epinefrin secara berlebihan sehingga menyebabkan jantung berdebar keras dan cepat. Hormon epinefrin diproduksi dalam jumlah banyak pada saat sedang cemas. Hormon epinefrin mempengaruhi otak akan membuat indra perasa merasa kebal terhadap sakit, kemampuan berpikir dan ingatan meningkat, paru-paru menyerap oksigen lebih banyak, glukogen diubah menjadi glukosa yang bersama-sama dengan oksigen merupakan sumber energi.

Detak jantung dan tekanan darah juga meningkat sehingga metabolisme meningkat. Molekul-molekul epinefrin 
memiliki fungsi khusus dalam pembuluh vena dan arteri yang memastikan bahwa organ-organ penting menerima lebih banyak aliran darah di saat bahaya dan karena itu, molekul-molekul ini melebarkan pembuluh darah menuju jantung, otak, dan otot. Sel-sel yang mengelilingi pembuluh merespon epinefrin dan mengalirkan lebih banyak darah yang dibutuhkan jantung. Dengan cara ini, darah tambahan yang dibutuhkan oleh otak, otot, dan jantung dapat dipasok, akibatnya darah akan mengalir dengan cepat dan banyak sehingga oksigen didistribusikan lebih banyak, dengan demikian pada orang yang cemas akan terjadi peningkatan curah jantung sekaligus peningkatan kebutuhan oksigen. Pembentukan kompleks adrenalin-reseptor akan menimbulkan depolarisasi dengan demikian depolarisasi yang terjadi di daerah motor end-plate (misalnya SA Node/miokardium) akan meningkat.

Peningkatan depolarisasi ini akan memperpendek wakfu istirahat otot jantung sehingga terjadi peningkatan frekwensi denyutan jantung. Peningkatan frekwensi ini akan mengakibatkan volume curah jantung bertambah sehingga jumlah darah yang dialirkan oleh jantung ke seluruh tubuh meningkat. Dengan kata lain, kehadiran adrenalin selain akan meningkatkan frekwensi denyut jantung jugu akan meningkatkan isi sekuncup jantung, dengan demikian maka curah jantung akan meningkat (Suryana, 2015).

\section{Kesimpulan dan Saran}

Terdapat kecemasan pada pasien pre operasi SC dan terdapat hubungan antara kecemasan dengan peningkatan cardiac output. Peningkatan cardiac output terjadi karena adrenalin meningkatkan depolarisasi dengan sehingga dapat memperpendek waktu istirahat otot jantung akhirnya heart rate meningkat yang selanjutnya diikuti peningkatan volume curah jantung sehingga jumlah darah yang dialirkan oleh jantung ke seluruh tubuh meningkat. Pada pasien pre operasi SC muncul kecemasan terkait proses operasi dan keselamatan baik bayi maupun ibu sehingga perlu diberikan penjelasan sedetail-detailnya tentang tindakan operasi pada saat melakukan inform consent agar pasien tidak mengalami kecemasan sebelum dilakukan prosedur SC selain itu perlunya menciptakan suasana yang nyaman diruang pre medikasi atau ruang tunggu pre operasi selain itu juga perlu dilakukan bimbingan pendekatan pada Tuhan YME (doa) untuk memberi rasa nyaman dan kesiapan saat operasi.

\section{Daftar Pustaka}

Abdurrahmat, Asep Suryana. 2015. Efek Adrenalin Terhadap Kerja Jantung. Jurnal Entropi Volume $X$. Jurusan Biologi FMIPA Universitas Negeri Gorontalo

Atkinson L., Ricard. 2003. Pengantar Psikologi Edisi XI Jilid 2 .Batam : Interaksara

Budi Anna Keliat, (2006).Proses Keperawatan Kesehatan Jiwa. Edisi 2. EGC. Jakarta

Burns, RB.Stuart, GW(2006), 'Buku saku keperawatan jiwa', Edisi Ke 5.

Cuningham, F.G. (2006). Obstetri Williams. Jakarta: EGC

El-Ardat M.A , Izetbegovic S , Djulabic A and Hozic A . 2014. Incidence of Cesarean Section at the Department of Gynecology and Obstetrics of Hospital in Travnik

Kasdu, Dini. 2003. Operasi Caesar Masalah dan Solusinya. Jakarta: Puspa Swara.

Kozier,B.,Glenora Erb, Audrey Berman and Shirlee J.Snyder. 2010. Buku 
ISSN Cetak 2303-1433

ISSN Online: 2579-7301

Ajar Fundamental Keperawatan.

Jakarta : EGC

Stuart, dkk. (2006). Buku Saku

Keperawatan Jiwa. Edisi 3

Jakarta : EGC

Vincen. J.L. 2008. Understanding cardiac output. Journal Critical care. BioMed Central.

W.B Cannon. 2002. Human emotion. American Journal of Public Health Vol 92, No. 10

Wulandari, Y. 2014. Analisis Tindakan

Persalinan Section Caesarea ditinjau dari Faktor Medis KESMAS, Vol.8, No.1 : Sragen. 